\title{
Nutrition and IGF Proteins in Chronic Malnutrition and Critical Illness
}

\author{
Pei-Ra Ling and Bruce R. Bistrian
}

\section{KEY POINTS}

- The systemic inflammatory response found in severe stress, or its persistence as seen in chronic diseases, can cause a rapid or prolonged catabolic hypermetabolic condition leading to accelerated energy and nitrogen loss that cannot be compensated by dietary intake and results in protein energy malnutrition.

- The catabolic response to systemic inflammation is the consequence of multiple factors including increased levels of proinflammatory cytokines and catabolic hormones, decreased concentrations of anabolic hormones and growth factors such as IGFs, as well as tissue resistance to their effects. Although nutritional therapy has beneficial effects, adequate nutrition support alone cannot overcome the catabolic effects induced by severe illness.

- Cytokines reduce the levels of IGF-I and impair the action of IGF-I directly, as well as indirectly, by altering the IGFBPs.

- The most effective nutrition support for patients with conditions of acute or chronic systemic inflammation is actively being studied. Specific amino acids, omega-3-fatty acids, and antioxidant vitamins are examples of anabolic nutrition therapies that may, with anabolic hormone therapy, be effective in the management of disease-related malnutrition.

\section{INTRODUCTION}

Severe injury, infection, and other critical illnesses, such as AIDS, cancer, and many chronic diseases, cause profound metabolic changes in the host to support the injury response, generally characterized by increasing the catabolism of certain tissues such as muscle and fat to mobilize stored nutrients while decreasing nutrient availability for growth. Net loss of body protein and fat mass results in adults, and growth cessation occurs in children. During the acute phase of the systemic inflammatory response, enhanced catabolism of endogenous protein and fat serve to meet the suddenly increased energy and amino acid requirement that is vital for a successful outcome. However, the intensity of the systemic inflammatory response found in severe stress, or its persistence as seen in chronic diseases, can cause a rapid, or prolonged, catabolic and hypermetabolic condition, leading to the exhaustion of energy and protein reserves in both instances. If such accelerated energy and nitrogen loss cannot be compensated by enhanced dietary intake, protein energy malnutrition (PEM) results. It has been 
reported that malnutrition is commonly observed both in hospitalized critically ill patients and patients with chronic diseases $(1-4)$. The unintentional loss of more than $10 \%$ of weight significantly contributes to the increased morbidity and mortality in critically ill patients (5). Approximately two-thirds of patients who die with advanced cancer suffer from cancer cachexia. For this reason, investigations into nutritional and other anticatabolic therapy to blunt catabolism in such patients have been an important research interest for many years.

The catabolic response to severe illness is the consequence of multiple factors that arise as components of the systemic inflammatory response, including decreased nutrient intake, increased levels of cytokines and catabolic hormones, and decreased levels of anabolic hormones as well as tissue resistance to their effects. Although nutritional therapy has beneficial effects in these patients, adequate nutrition support alone cannot overcome the catabolic effects induced by severe illness (6-8). The relative ineffectiveness of nutritional therapy under such conditions could be caused by the failure to modify the impact of endogenous catabolic and antianabolic factors associated with severe illness. New therapies, including anticytokine strategies and pharmacologic doses of anabolic hormones, particularly growth hormone, insulin-like growth factor, and anabolic steroids, are currently being investigated for their role in the prevention or amelioration of lean tissue loss during catabolic states. Previous chapters have extensively reviewed various aspects of IGF-I system under different physiological and pathological conditions. In this chapter, we will briefly review the mechanisms responsible for the development of protein energy malnutrition in critical illnesses, particularly the role of cytokines in protein malnutrition. Subsequently, attention will be focused on nutrition support in critical illness, including the optimal levels of energy and protein intake, the effects of omega- 3 fatty acids, and the potential role of major anabolic hormones and vitamin and antioxidant supplementation for improvement in the efficacy of nutritional repletion in severe acute or chronic activation of the systemic inflammatory response.

\section{CYTOKINES: MAJOR FACTORS CONTRIBUTING TO THE DEVELOPMENT OF MALNUTRITION}

\subsection{Effects of Cytokines on Protein Metabolism}

It has been long appreciated that there is a catabolic nitrogen response to fever and infection $(9,10)$. Early studies demonstrated that factor(s) derived from white blood cells, originally termed leukocyte endogenous mediator, could be responsible for these responses $(11,12)$. Subsequently, a number of different peptides that share some of the actions under the general term leukocyte endogenous mediator have been identified. All of these proteins, a family with over 80 members and still growing, are called cytokines. Tumor necrosis factor (TNF), interleukin (IL)-1, and IL-6 are postulated as the three major cytokines responsible for wasting during critical illness $(13,14)$.

Over the past several years, evidence has accumulated that the levels of circulating TNF- $\alpha$, IL-1, and IL- 6 are elevated in critically burned patients and in patients with septic shock or severe sepsis (15-18). The increased serum levels of these cytokines, particularly IL-6, can be a sensitive predictor of mortality in patients with septic shock (19-23), cancer $(24)$, and some chronic diseases $(25,26)$, suggesting that these cytokines are major contributors to wasting in critical illness. In many chronic illnesses the evidence for the 
presence of a systemic inflammatory response often require the use of more sensitive measures such as serum levels of soluble TNF receptors (27) or acute phase proteins like C-reactive protein $(28,29)$ because of the lower intensity of inflammation

Advances in recombinant technology have made it possible to investigate the roles of individual cytokine in wasting. In our laboratory, major proximal cytokines in recombinant form, IL- $1 \beta$ and TNF- $\alpha$, alone and in combination, have been investigated for their effects on protein metabolism (30). Studies using both acute and chronic infusion of IL-1 $\beta$ into rats and matched pair-fed controls demonstrated that IL-1 infusion at $20 \mu \mathrm{g} / \mathrm{kg} / \mathrm{d}$ for $6 \mathrm{~d}$ caused weight loss and urinary nitrogen loss, reduction of plasma zinc concentration and increased energy expenditure (31). In this study, dynamic protein metabolism was assessed by the continuous infusion of tracer. At a steady state, estimates of protein synthesis were calculated based on the incorporation of the tracer from the tissue free amino acid pool into the protein bound pool (32-34). Protein breakdown was determined from the dilution of specific radioactivity in the tissue free amino acid pool relative to the plasma pool $(35,36)$. The algebraic sum of these isotopic estimates of protein synthesis and breakdown rates was in general agreement with independent assessment of tissue growth. The results showed that IL-1 significantly decreased the rate of protein synthesis in muscle and increased leucine release from skeletal muscle tissue as compared to control (saline infusion). Moreover, IL-1 significantly increased urinary 3-methylhistidine excretion, reflecting skeletal muscle protein catabolism (31). Using the same tracer model, the effects of TNF (100 $\mu \mathrm{g} / \mathrm{kg} / \mathrm{d})$ and IL-1 (20 $\mu \mathrm{g} / \mathrm{kg} / \mathrm{d})$, either alone or in combination, on protein metabolism were also compared in rats after $6 \mathrm{~d}$ of infusion (37). Both TNF and IL-1 significantly reduced food intake and caused weight loss, net nitrogen loss and skeletal muscle catabolism, whereas liver weight was increased. Isotopic study also showed that the significant changes in skeletal muscle and whole body protein catabolism were greater for both cytokine groups containing TNF (i.e., TNF and IL/TNF) compared with IL-1. Although both IL-1 and TNF have been demonstrated to participate in protein catabolism through decreases in expression of eukaryotic initiation factor-2 $\mathrm{B} \varepsilon$ (eIF-2BE) (38-40), these results suggest that there are different mechanisms for host wasting in response to IL-1 and TNF. For instance, it has been demonstrated that glucocorticoids (41), and nuclear factor-kappaB (NF- $\mathrm{BB}$ ) activation (42) are essential to mediate TNFinduced catabolism but not IL-1. However, both IL-1 and TNF induce anorexia, and the reduced food intake in human and animals will decrease the rate of protein synthesis and muscle growth. Therefore, by having a semistarved control group in both our studies, the effects of cytokines and/or food restriction on nitrogen loss and protein metabolism at the whole body level and in muscle could be identified. Our data showed that the effects of cytokines were independent from and additive to those resulting from semistarvation $(31,37)$. Other studies also demonstrated that pretreatment of rats with IL- 6 for $6 \mathrm{~h}$ induced fever and increased the release of tyrosine and 3 -methylhistidine in incubated extensor digitorum muscle in an ex vivo system, suggesting that IL-6 also augments muscle proteolysis (43). However, it is not clear whether the proteolytic-inducing effects of IL- 6 are direct or require the release of other mediators, such as TNF and IL-1.

The role of cytokines in wasting in critical illnesses is also confirmed by modifying the release and/or biological activity of cytokines using anticytokine antibodies or 
cytokine receptor antagonists. Blockade of IL-1 action by administration of IL-1 receptor antagonist (IL-1ra) to experimental animals prevents muscle proteolysis in response to endotoxin (44). However, anticytokine antibodies and receptor antagonists are specific for an individual cytokine. Infusion of a single cytokine can stimulate the production of other cytokines in vivo whereas endotoxin or disease elicits the production of many cytokines. Thus, one single anticytokine antibody may not efficiently limit muscle wasting, particularly if given post exposure. Moreover, it also is difficult to know whether the effect of anti-cytokine antibodies to reverse catabolism is a direct or indirect effect. For instance, the administration of IL-1ra significantly inhibits the neutrophilia and the induction of corticosterone secretion by IL-1, the latter action being anti-catabolic. Mice with deletions for IL-1, TNF, or IL-6 genes can specifically define which cytokine knockout mice express physiological deficits. In IL-6 gene-deficient mice, for example, anorexia, cachexia, and lethargy in response to administration of LPS and turpentine are suppressed $(45,46)$, suggesting IL-6 contributes to the development of wasting during critical illnesses. All these experimental data provide strong evidence that cytokines do play unique and important roles in wasting.

\subsection{Effects of Cytokines on Anabolic Hormone Actions}

\subsubsection{INSULIN}

It has been recognized that resistance to the actions of anabolic hormones, including insulin, growth hormone, and IGF-I, appears to be a significant contributing factor to the catabolic response during severe stressful illness, advanced HIV infection and cancer. Evidence suggests that the resistance to anabolic hormones is related to the release of cytokines during critical illness.

We conducted a study (47) to characterize the effects of endotoxin, TNF, and IL-1 on the glucoregulatory action of insulin in the rat using the euglycemic hyperinsulinemic clamp technique. Results showed that the glucose infusion rate necessary to maintain similar glucose levels at similar hyperinsulinemic conditions varied significantly according to treatment. Animals receiving saline infusion required $4.2 \pm 2.5$ mmol glucose/kg.h to maintain normoglycemia, which was the highest level among the five groups. Animals that received IL-1 infusion required slightly but not significantly less glucose, $3.4 \pm 0.3 \mathrm{mmol}$ glucose $/ \mathrm{kg} / \mathrm{h}$, as compared with saline infusion. With TNF infusion, the requirement for maintenance of normoglycemia was $2.3 \pm 0.5$ $\mathrm{mmol}$ glucose $/ \mathrm{kg} / \mathrm{h}$. Animals receiving endotoxin infusion required only $1.9 \pm 0.5$ $\mathrm{mmol}$ glucose $/ \mathrm{kg} / \mathrm{h}$. Animals treated with the combination of TNF and IL-1 required the lowest amount of glucose, $1.0 \pm 0.3 \mathrm{mmol}$ glucose $/ \mathrm{kg} / \mathrm{h}$. Thus these data suggested that endotoxin, TNF, and possibly IL-1 can rapidly induce a state of insulin resistance. However, the loss of insulin sensitivity is tissue specific in these animals. It has been noted that under certain conditions, such as in patients with HIV lipodystrophy (48), the state of insulin resistance is more pronounced in skeletal muscle than in liver or fat. Similarly, the resistance to elevated insulin may only be present in nontumor tissues in patients with cancer (49).

TNF significantly decreases insulin receptor autophosphorylation, tyrosine phosphorylation of endogenous IRS-1, and kinase activity (50), which may provide the molecular mechanisms to explain insulin resistance that develops under conditions of excess cytokine production. Endotoxin, for example, markedly diminished insulin- 
stimulated insulin receptor and IRS-1 tyrosine phosphorylation (51-53). Using the pair-feeding method, we also found that endotoxin inhibited insulin-stimulated tyrosine phosphorylation of insulin receptor (50\%), IRS-1 (62\%), and IRS-2 (approx $100 \%$ ) in muscle tissue as compared with pair-fed controls (54). Because the nutritional conditions in both groups were controlled at a similar level, our results further suggest that cytokines released during endotoxin infusion induce insulin resistance through defects at many steps in the insulin signaling pathway, and that such effects are direct and independent from the malnutrition induced by food restriction.

Cytokine-induced stress hormones, such as glucocorticoids and epinephrine, also contribute to anabolic hormone resistance in critical illness. Glucocorticoids are known to impair insulin-mediated glucose uptake in skeletal muscle by inhibiting translocation of the Glut 4 glucose transporter (55). Infusion of epinephrine in the absence of other hormones impairs insulin-mediated glucose uptake (56). Under experimental conditions in which critical illness was mimicked by the infusion of multiple stress hormones, discontinuation of epinephrine infusion while maintaining other hormones resulted in a rise in plasma insulin, improvement of insulin sensitivity and reduction of free fatty acid levels (57).

\subsubsection{Growth HoRmone-IGF AXIS}

Growth hormone resistance is also a common feature of critical illness, characterized by growth hormone hypersecretion and very low IGF-I levels as a result of acquired peripheral growth hormone resistance and malnutrition. In catabolic states, it is thought that the decreased tissue abundance of growth hormone receptor in liver and muscle contributes at least in part to $\mathrm{GH}$ resistance $(58,59)$. After endotoxin administration into the rat ( $4 \mathrm{~h}$ after $1 \mathrm{mg} / \mathrm{kg}$ of endotoxin), we further found there was a marked decrease in GH-stimulated receptor tyrosine phosphorylation (70\%), phosphorylation/Jak2 (50\%) and STAT5 phosphorylation (40\%) in the liver (60). Thus, during critical illness the defects in both receptor abundance and postreceptor signaling responses to growth hormone stimulation may be responsible for the development of growth hormone resistance. The neuroendocrine effects of critical illness on the GH/IGF axis are more thoroughly discussed in Chapter 16, and the effects of IGF proteins on protein balance in Chapter 11.

Cytokines not only reduce the levels of IGF-I but also impair the action of IGF-I. The ability of IGF-I to stimulate protein synthesis is impaired by TNF- $\alpha$, at serum levels as low as $2 \mathrm{ng} / \mathrm{mL}$ and as soon as after $10 \mathrm{~min}$ of exposure in human myoblasts (61). In a study with a TNF infusion protocol ( $20 \mu \mathrm{g} / \mathrm{kg}$ of TNF infusion for $3 \mathrm{~h}$ ), TNF significantly inhibited the action of IGF-I $(200 \mu \mathrm{g} / \mathrm{kg})$ to lower plasma glucose levels indicated by less glucose required to maintain euglycemia as compared with saline infusion (62). Because this dose of IGF-I did not suppress insulin secretion, it seems the inhibition by TNF on IGF-I-induced glucose utilization is independent of insulin action. Consistent with our findings, Fang et al. reported that cytokines blocked the effects of IGF-I on glucose uptake in incubated muscle (63). However, it also appeared that the inhibition of glucose use by TNF could be readily overcome by the provision of increased amounts of IGF-I $(400 \mu \mathrm{g} / \mathrm{kg})$ even though insulin levels were significantly decreased as compared with low dose of IGF-I $(200 \mu \mathrm{g} / \mathrm{kg})(62)$, suggesting that the resistance to IGF-I might occur at a step distal to IGF-I receptors. In contrast to these findings, Lang (64) reported 
that under euglycemic and hyperinsulinemic conditions the effects of IGF-I on glucose uptake in the gastrocnemius, soleus, and heart muscle were similar between control and septic rats, although the desensitized insulin receptor with association of IRS- 1 and IRS2 may have resulted in cell resistance to both insulin and IGF-I (65).

In the circulation, the levels of free IGF-I are considered to be most relevant to the biologic activity of IGF-I. However, the levels of IGF binding proteins (IGFBPs) also regulate the action of IGF-I. At least six distinct IGFBPs have been characterized (66). IGFBP-3 generally responds in parallel with IGF-I and is most important for the maintenance of IGF-I in the circulation, whereas IGFBP-1 and -2 may inhibit IGF-I activity. TNF, IL-1, and IL-6, produce dose- and time-dependent increases in IGFBP-1 production in HepG2 cells in the liver of C57BL/6 mice $(67,68)$. In a study monitoring IGF-I and IGFBPs levels in intensive care unit patients during a 30-d period, serum levels of IGF-I, IGFBP-3 and acid-labile subunit were low on admission and remained low over $30 \mathrm{~d}(69)$. In contrast, IGFBP-I levels were high on admission, correlated with early changes in negative nitrogen balance, and fell rapidly during the first week. Moreover, proteolytic degradation of circulating IGFBP-3 was increased, leading to a reduced ability to form the IGFBP-3 ternary complex $(69,70)$. Taken together, these data suggest that cytokines also inhibit IGF-I action indirectly through alterations in IGFBPs during critical illness.

\section{NUTRITIONAL MANAGEMENT IN CRITICAL ILLNESS}

\subsection{Overview}

Critically ill patients are hypermetabolic and have anabolic inefficiencies that lead to increased requirements for certain nutrients. The metabolic changes that characterize the systemic inflammatory response provide a reordering of priorities in relation to metabolic homeostasis. On one level, there are the essential nutrients, some of which like protein and certain vitamins may be required in somewhat greater amounts, whereas others like iron may need to be withheld in the early phase of injury. In addition, the heterogeneity of the patient population, including different degrees of trauma or injury, different types of tumors and different stages of chronic diseases such as hepatic and renal insufficiency, make it more difficult to provide or develop nutritional guidelines applicable to all malnourished patients. Over the past three decades, nutrition support methods by total parenteral nutrition (TPN) or tube feeding (enteral nutrition) have been developed. These invasive feeding techniques provide exciting tools that may allow certain nutrients to perform new and unique roles, such as reducing the intensity of the systemic inflammatory response by their antioxidant (selenium, glutamine, zinc) or anti-inflammatory (omega-3 fatty acids) effects. In general, current nutritional approaches have been designed to respond to special nutritional needs created by the catabolic state. The rationale of nutrition therapy for critically ill patients, therefore, is largely based on clinical judgment. Since nutritional assessment is reviewed in chapter 4 , the discussion will be limited to some important aspects of nutritional management, including levels of calories and protein needed, effects of special nutrients on modulation of acute-phase response and the use of anabolic agents in conjunction with adequate nutrition support to critically ill patients.

\subsection{Protein Metabolism and Requirements in Critical Illness}

The metabolic responses to critical illness differ significantly from those of starvation and food restriction. During starvation and food restriction, the body attempts to 
adapt to undernutrition by reducing energy expenditure and limiting protein catabolism. With the fall in food intake, glycogen stores are exhausted within the first 24-72 $\mathrm{h}$, suggesting that carbohydrate oxidation rates are altered rapidly to reflect reduced intake. Studies on glucose metabolism have revealed that underweight individuals have higher rates of glucose use per unit of lean body mass accomplished by increasing insulin sensitivity, as compared with normal middle-aged men (71). As an alternate fuel, fat becomes the principal energy source sparing body protein by limiting the need for gluconeogenesis. During longer starvation periods, protein breakdown is further decreased in order to conserve nitrogen and maintain lean body mass. When rates of whole body protein synthesis were measured in the undernourished state (body mass index $16.7 \mathrm{~kg} / \mathrm{m}^{2}$ ) and a normal state (body mass index $20.8 \mathrm{~kg} / \mathrm{m}^{2}$ ), total body protein synthesis and breakdown rates per unit of fat free mass were unchanged in the undernourished state (72). This ability, which is essential for conserving nitrogen when intake is reduced, is absent in most critically ill patients. In critical illness, the rate of lean tissue loss can be up to seven times greater than in well-adapted starvation $(73,74)$. Whole-body protein synthesis is diminished in skeletal muscle and connective tissue in animal models of cytokine-produced catabolism (75). Although insulin resistance develops and the percentage contribution of fat to energy expenditure is reduced, total fat oxidation plus protein and carbohydrate oxidation are all increased with the increases in energy expenditure present in critical illness. Interestingly, at the same time, liver fractional rates of protein synthesis are increased in this condition, accounting for the increase in liver size as well as the production of the so-called acute-phase proteins, although there is a concomitant decrease in albumin synthesis. The greatest impact to lower serum albumin concentrations results from the systemic inflammatory response and specifically the IL-6 effects, which reduce albumin synthesis, increase its catabolism, and cause extravascular extravasation. Anorexia limiting protein and energy intake makes only a minor contribution to the development of hypoalbuminemia. Thus, in critical illness conditions, hypoalbuminemia is primarily a marker of the systemic inflammatory response that produces protein-malnutrition, rather than being a direct measure of protein-energy malnutrition per se (76).

In a healthy adult consuming a diet without protein, there is an obligatory loss of 20 to $30 \mathrm{~g}$ of protein per day. A level of $55 \mathrm{~g}$ of protein intake per day $(0.8 \mathrm{~g}$ of protein $/ \mathrm{kg} / \mathrm{d}$ ) is recommended to prevent a net protein loss in healthy individuals (77). For critically ill patients, substantially more protein is required to account for anabolic inefficiencies. Protein intake ranging from 1.0 to $1.5 \mathrm{~g}$ of protein $/ \mathrm{kg} / \mathrm{d}$ is recommended to attenuate protein loss. In the most severe inflammatory states, the delivery of more than $1.75 \mathrm{~g}$ of protein $/ \mathrm{kg} / \mathrm{d}$ only increases urea formation (78-80) making this the upper effective level of protein intake. Although a positive nitrogen balance is desired, net protein anabolism can usually only be achieved after the systemic inflammatory response subsides. During the acute phase, however, energy intakes that meet energy expenditure and protein intake at $1.5 \mathrm{~g} / \mathrm{kg}$ will preferentially support the systemic inflammatory response by fostering host immune function and wound healing whereas losses of lean tissue are limited principally to skeletal muscle (81).

\subsubsection{SPECIFIC AMino ACIDS}

Certain amino acids have unique importance for critically ill patients. The branchedchain amino acids (leucine, isoleucine and valine) are essential amino acids. Studies 
have shown that these amino acids have additional effects on stimulation of protein synthesis in muscle and on nonbranched chain amino acid uptake in the liver for protein synthesis (82). Glutamine, arginine, and cystine are considered to be conditionally essential amino acids because the levels of these amino acids are often low in plasma and tissues following stress. In studies in rats, a higher protein intake elevates plasma IGF-I levels (83-84), and pharmacological doses of arginine increase serum levels of growth hormone and IGF-I (85). Amino acid limitation, as occurs during dietary protein deficiency, inhibited endogenous IGF-I production (86) but induced IGFBP-1 expression in hepatic cells (87). Moreover, a clinical study with glutamine-enriched enteral nutrition in 72 multiple trauma patients demonstrated a significant reduction in infection, although this did not translate into a significant reduction in hospital stay (88). In a second study of trauma patients using a formula, containing not only glutamine but also arginine, omega- 3 fatty acid, and nucleotides, there was a significant reduction in infection rate and hospital length of stay (89). Although diets that have enriched concentrations of specific amino acids have not always shown consistent benefits, growing evidence suggests that supplementation with several of these amino acids improves nitrogen balance $(90,91)$, can decrease infectious complications and enhance immune system function (92-94), which is of great potential clinical interest.

\subsection{Energy Requirements}

Provision of carbohydrate and lipids are also required as sources of energy to minimize protein degradation and lipolysis. Although increasing energy intake above energy requirements may improve protein use in unstressed individuals, there is little evidence for such an effect in critically ill patients. In fact, excess administration of either fat or carbohydrate in this setting can have adverse effects including increasing the risk for infection. Thus, the present recommendation for energy intake is that total energy provision should not exceed energy expenditure in critically ill, malnourished patients. For most medical or surgical patients with mild-to-moderate stress, energy goals are to achieve energy balance, which approximates $25-30 \mathrm{kcal} / \mathrm{kg} / \mathrm{d}$. Although patients with severe trauma may have energy expenditures substantially higher, at $35-40 \mathrm{kcal} / \mathrm{kg} / \mathrm{d}$, increasingly an upper limit of $30-35 \mathrm{kcal} / \mathrm{kg} / \mathrm{d}$ is being used in the acute phase of injury to avoid metabolic complications $(95,96)$. In the acute stage of critical illness, metabolic adaptive responses are characterized by hyperglycemia due to central and peripheral insulin resistance, accompanied by a hyperdynamic cardiovascular response including high cardiac output, increased oxygen consumption, high temperature and decreased peripheral vascular resistance. Hyperglycemia is particularly common when patients are fed greater than $35 \mathrm{kcal} / \mathrm{kg} / \mathrm{d}$, which can markedly increase the risk for infection (97). For instance, it has been demonstrated that provision of dextrose at rates of $4 \mathrm{mg} / \mathrm{kg} / \mathrm{min}(5.7 \mathrm{~g} / \mathrm{kg} / \mathrm{d})$ intravenously often is associated with hyperglycemia even in the nondiabetic host (98) because of the insulin resistance, which is universal in stressed, hospitalized patients (96). A study from our hospital showed that the presence of a blood glucose $>220 \mathrm{mg} / \mathrm{dL}(12.2 \mathrm{mmol} / \mathrm{L})$ on the first postoperative day was associated with a greater than fivefold increased risk of serious infection in diabetic patients (99). Recent evidence also suggests that hyperglycemia can exacerbate inflammation through either induction of oxidative stress $(100,101)$ or acquired immunodepression (102). None of these effects is desirable in the critically 
ill. Although energy balance may not be achieved in some cases by caloric intakes at 25-30 kcal/kg/d, the lower risk for hyperglycemia may lead to an improved clinical outcome. However, hyperglycemia is usually easily treatable by insulin with substantial clinical benefits in randomized trials in humans (103-105) and in endotoxininduced stress in rats (106) and is preventable by limiting caloric intake $(97,107)$. Insulin is a potent anabolic hormone and stimulates muscle protein synthesis. Thus, provision of adequate nutrients with exogenous insulin in prevention of hyperglycemia should enhance muscle anabolism. In general, the goal of nutritional support in the critically ill is to provide support for the systemic inflammatory response including enhancing immune function, repairing injured tissues and healing wounds. Restoration of lost lean tissue is generally not possible until the systemic inflammatory response abates, although the initial losses of lean tissue in the acute phase generally abates and is ultimately reversed by a combination of developing malnutrition and a less intense inflammatory response in those with prolonged illness.

A lower caloric intake approximating resting rather than total energy expenditure while including all other essential nutrients and at least $1 \mathrm{~g} / \mathrm{kg} / \mathrm{d}$ of protein may often be more in accordance with the inflammatory and hormonal mediator climate during the first few days and for up to $10 \mathrm{~d}$ of systemic inflammation. Although the effects of hyperglycemia are not often considered in planning nutritional support, it is important to maintain glycemia $<220 \mathrm{mg} / \mathrm{dL}(11.1 \mathrm{mmol} / \mathrm{L})$ in diabetic patients and 180-200 mg/dL (9.1-10.0 $\mathrm{mmol} / \mathrm{L})$ in nondiabetic patients to minimize complications in patients receiving enteral and particularly parenteral nutrition support. Even tighter control blood glucose level at $80-110 \mathrm{mg} / \mathrm{dL}$ may be justified in the critically ill (95). The nutritional goal for these patients still remains the achievement of net anabolism by advancing caloric intakes to estimated total requirements as tolerated and metabolic homeostasis allows. In general, when a patient's nutritional requirements cannot be met via the oral route for period of 5-7 d (or less if the patients is initially malnourished), parenteral or enteral nutrition is indicated. In chronically malnourished patients, it is well recognized that wound healing and normal immune responses are dependent upon adequate nutrient intake. Therefore, it seems reasonable to start feeding as soon as possible after malnutrition is diagnosed. Early feeding may decrease complication rates and improve quality of life in these patients. For patients with severe stress (multiple trauma, closed head injury, major burns and severe sepsis) who are often well nourished at the onset of their illness, early nutrition support within the first few days should also improve outcome as a result of the intensity and the likelihood for a prolonged duration of the inflammatory response. In patients requiring home TPN, who generally have minimal levels of metabolic stress, a total caloric intake at $35 \mathrm{kcal} / \mathrm{kg} / \mathrm{d}$ is recommended at the initiation of nutrition support to rapidly replete the cumulative calorie deficit so as to achieve weight gain, and then intake adjusted to a lower level to maintain desired body weight.

\subsection{Lipid Metabolism and Recommendations}

Lipid is an energy source with high caloric density $(9 \mathrm{kcal} / \mathrm{g})$. Compared with diets exclusively of carbohydrate and protein, an adequate intake of fat can result in better nutrient utilization, less $\mathrm{CO}_{2}$ production and decreased lipogenesis and insulin requirements (108). Provision of fat intake in TPN formulations is also essential to prevent essential fatty acid deficiency (109-111). The ideal ratio of fat and carbohydrate is 
unknown, but high-fat feeding can enhance stress-stimulated corticosterone levels in the rat (112). In our hospital, 20-40 $\mathrm{g}$ fat/d for 40-80 kg body weight is recommended. For intravenous delivery, it is important to control the rate at an upper limit of 0.11 $\mathrm{g} / \mathrm{kg} / \mathrm{h}$ in critically ill patients to avoid the potential for adverse outcomes (113). Malnourished patients with intact gastrointestinal function should be given adequate dietary fat, which can range from $3 \%$ to $30 \%$ of calories in commercial enteral formulas and usually $30-35 \%$ in calories based on food, although surgery or disease may reduce intestinal absorptive capacity. The minimal fat requirements for the prevention of essential fatty acid deficiency are at least $3.2 \%$ total calories given as intravenous fat $(114,115)$. The minimal daily requirement for dietary linolenic acid $(18: 3 \omega-3)$ is unknown, because dietary deficiency of $18: 3 \omega-3$ in a normal adult consuming food orally has not been described but is assumed to be about $0.5 \%$ of total calories.

\subsubsection{Omega-3 Fatty ACIDs ( $\omega$-3 Fatty ACIDS)}

As described above, the accelerated catabolism, rapid onset of malnutrition, and immune system failure is related to the excessive production of cytokines underlying the systemic inflammatory response. Substantial evidence has accumulated that fish oil, which is rich in $\omega-3$ fatty acids, can significantly suppress cytokine release from monocytes (116) and attenuate the metabolic response to inflammation or infection. Effects noted in experimental studies in animals have included dampening of the febrile response (117), decreasing serum lactate concentration and improving lung morphology (118), decreasing insulin resistance $(116,117)$, and improving survival (119), all after endotoxin challenge. Clinical studies in humans have shown improved outcome in critical illness (120), rheumatoid arthritis $(121,122)$, inflammatory bowel disease $(123,124)$, and renal transplantation (125) to name but a few conditions. The intravenous fat currently available for use in United States is soybean oil, which has high content of polyunsaturated fatty acids (mainly $\omega-6$ fatty acids). In rats, it has been demonstrated that dietary $\omega-6$ polyunsaturated fatty acids significantly increase the levels of hepatic IGFBP-1 transcripts and protein, which is independent of any caloric effects of the diets and the levels of insulin (126). Thus, these findings suggest that certain fats can be viewed as potential therapeutic agents during critical illness rather than purely as an energy source.

Although many potential mechanisms have been proposed for the clinical benefits of fish oil feeding, the anti-inflammatory effects of fish oil are thought to principally occur through a reduction in arachidonic acid (AA) content of phospholipids within cell membranes. Eicosapentaenoic acid (EPA, 20:5 (22:6 $\omega 3)$, which are enriched in fish oil, are preferentially and rapidly incorporated into membrane phospholipid to displace AA. Moreover, EPA is structurally similar to AA and competes with AA in the cyclo-oxygenase pathway, which leads to the synthesis of a different series of prostaglandins, thromboxanes, and prostacyclins that have substantially less immune suppression, proinflammatory, and hypotensive effects (127-130). These properties of $\omega-3$ fatty acids may have application in the treatment of chronic inflammatory disease, as well as in the more acute situation such as acute respiratory distress syndrome or patients undergoing chemo/radiation therapy (131-134). It is speculated that lipid emulsions with a $\omega-3 / \omega-6$ fatty acid ratio of $1: 2$ would induce the highest leukotriene $\mathrm{C}_{5} /$ leukotriene $\mathrm{C}_{4}\left(\mathrm{LTC}_{5} / \mathrm{LTC}_{4}\right)$ ratio and exert the most favor- 
able modulation of lipid mediator synthesis $(135,136)$. Recently, a study in laboratory animals demonstrated that during sepsis a fish oil-supplemented diet with 1:1 fish oil and soybean oil emulsion significantly improved the survival rate and prevented the sepsis-induced suppression of lymphocyte proliferation and IL-2 release (137).

The definition of cancer patients who might benefit from dietary $\omega-3$ fatty acids has only just begun. Clinical studies with EPA-containing fish oil have shown it to be effective in attenuating the development of weight loss in patients with pancreatic cancer. In a trial of 18 patients with unresectable pancreatic cancer orally receiving fish oil capsules $(1 \mathrm{~g})$ containing eicosapentaenoic acid $18 \%$ and docosahexaenoic acid 12\%, 11 patients showed weight gain, three became weight stable, and four continued to lose weight but at a reduced rate (138). Weight gain was seen in other studies where EPA $(2.1 \mathrm{~g} / \mathrm{d})$ was administered together with adequate calorie and protein supplement $(139,140)$. Moreover, the percentage body water was maintained, suggesting that the weight gain was not the result of the accumulation of water. Body composition analysis further suggested that there was no change in fat mass, opposite to what would be expected from nutritional supplementation alone (141). It appears that provision of a fish oil-enriched nutritional supplement in patients with pancreatic cancer results in some normalization of the metabolic response, in association with an improvement in nutritional status. Such effects might improve the quality of life and increase survival time in these patients. However, further studies are needed to test whether EPA is effective in patients with other types of tumors.

\subsection{Anabolic Hormones}

The administration of anabolic hormones, such as insulin, growth hormone, IGF-I, and anabolic steroids, in pharmacological amounts represents an approach to overcome the resistance to their actions and reverse the protein energy malnutrition response to acute illness or chronic disease. The availability of recombinant hormones has made some of these agents clinically available for study and use in catabolic states.

Currently, insulin is extensively used only to overcome TPN-induced hyperglycemia as a standard procedure. It has been demonstrated that administration of growth hormone to critically ill patients can enhance the levels of IGF-I and promote tissue anabolism under certain circumstances (142-147). One study even showed that such effects of growth hormone in protein synthesis were achieved in patients receiving only intravenous dextrose or parenteral nutrition with a small amount of nitrogen (148). Schambelan et al (149) examined the effect of $12 \mathrm{wk}$ of growth hormone therapy on the body composition and work capacity of HIV-infected individuals who had lost weight. They found that growth hormone increased lean body mass, reduced body fat, and increased treadmill work capacity. However, growth hormone has not consistently demonstrated net anabolic effects on nitrogen economy, because the improvement in nitrogen balance was not always statistically significant. Recent studies (150) investigated the effects of high dose growth hormone (range from 0.07 to $8.0 \mathrm{mg} / \mathrm{kg} / \mathrm{d}$ ) on clinical outcome in critically ill adults receiving prolonged intensive care. The results showed that growth hormone administration was associated with an increase in morbidity and mortality. Two potential side effects with growth hormone administration, hyperglycemia and fluid retention, are particularly likely to be a problem for the critically ill. Several other studies also suggest that if patients are severely infected, or have 
cancer, the response of growth hormone treatment may be impaired $(151,152)$. These results suggest that growth hormone is more likely to be effective when the systemic inflammatory response is mild to moderate. Therefore, despite the fact that growth hormone has proven to be clinically useful in a variety of conditions, it should still be considered as an experimental tool, because its advantages and disadvantages in various conditions need to be defined along with dosage requirements. Its value in reversing catabolic states in cachectic diseases, such as cancer, trauma, infection, and in postoperative care, have not been fully established yet.

IGF-I is an important mediator of the growth promoting effects of growth hormone. Although the effects of IGF-I have also been evaluated, large parenteral doses are required to promote specific anabolic activity. In addition, the action of IGF-I diminishes with time because of enhanced binding activity. Since the negative feedback of IGF-I alters GH and IGF BP elaboration and interacts with insulin effects, it has been suggested that the use of combination therapy of GH + IGF-I or the IGF-I + IGFBP3 molecule might be more beneficial. However, there is no condition of malnutrition where this therapy has been established clinically.

Other anabolic hormones, such as anabolic steroids, have been investigated in a variety of malnourished states, particularly AIDS wasting. The rationale for the use of androgenic steroids in chronic illnesses is based on the fact that there is a high frequency of low testosterone levels in HIV-infected men and that low testosterone levels in these patients are associated with poor disease outcomes and impaired muscle function. Studies in renal failure $(153)$ and AIDs $(154,155)$ have demonstrated improved restoration of lean tissue structure and function. However, the overall benefits of these drugs are undefined in patients with critical illness.

\subsection{Micronutrients and Antioxidants}

Micronutrients play a key role in many of the metabolic processes for promotion of survival from critical illness. However, a deficiency state can develop in the critically ill because of decreased nutrient intakes and increased requirements. For instance, sepsis or adult respiratory distress syndrome can dramatically increase the production of reactive oxygen species and lead to oxidative stress and activation of the transcription factor NF$\kappa \mathrm{B})$. In the rat, burn injury produced cardiac NF- $\mathrm{kB}$ nuclear migration $4 \mathrm{~h}$ after burn and cardiomyocyte secretion of TNF, IL-1, and IL- 6 by $24 \mathrm{~h}$ after the burn (156). It has also been demonstrated that vitamin A deficiency results in the decrease of serum IGF-I levels, which is accompanied by lower levels of IGF-I mRNA in rat liver (157). Zinc deficiency produced lower serum IGF-I and liver IGF-I mRNA, lower serum IGFBP3, lower liver growth hormone receptor and its mRNA, and lower serum growth hormone binding protein and its mRNA (158). In these rats, exogenous growth hormone did not enhance the levels of serum IGF-I and its liver mRNA, although the restoration of growth hormone receptor and growth hormone binding protein to normal was achieved by continuously infused bovine growth hormone in these rats. Thus, IGF-I synthesis may require the presence of zinc in addition to growth hormone (discussed in Chapter 5).

In general, serum antioxidant vitamin and trace element concentrations, such as vitamin C, vitamin E, selenium, and zinc, are seen to decrease with systemic inflammation. The logical answer to enhancing micronutrient concentrations is to provide dietary supplementation. There are only a limited number of studies that test the effi- 
cacy of antioxidant compounds in critical ill patients. Physiologic selenium replacement in critically ill patients receiving parenteral nutrition restored serum selenium and glutathione peroxidase levels to normal, and reduced the need for hemodialysis as well as mortality although the latter effect was not significant (159). In a prospective, randomized, double-blind, placebo-controlled study (160), 20 patients were randomized to receive a formula supplemented with vitamin A $(67 \mu \mathrm{g} / \mathrm{dL}), \mathrm{C}(13.3 \mathrm{mg} / \mathrm{dL})$, and E $(4.94 \mathrm{mg} / \mathrm{dL})$, and 17 patients received an isocaloric and isonitrogenous control solution. Administration of the supplemented solution significantly increased the concentration of plasma $\beta$-carotene, plasma and low-density lipoprotein-bound $\alpha$-tocopherol and improved low-density lipoprotein resistance to oxidative stress compared with controls, as assessed by ex vivo testing. However, there was no clinical benefit identified despite the fact that glutathione status was compromised and correlated with glutathione concentrations in critically ill patients. Parenteral glutamine administration with total parenteral nutrition, which might be expected to enhance glutathione levels, significantly reduced infections and hospital stay in patients undergoing bone marrow transplant (161) and major surgery $(162,163)$. Enteral glutamine in trauma patients led to a significant reduction in infection rate in one study (164) and in infection rate and length of hospital stay in another (165). However, glutamine has a multitude of other effects that may in some part played a role as well as the unknown contribution of other bioactive compounds contained in the various formulas. All these findings suggest that consideration of dietary components that alter antioxidant/oxidant status may influence the course of inflammatory and/or autoimmune diseases. On one hand, antioxidant levels are diminished but oxidative stress quite clearly increased by severe illness; therefore, reactive oxygen species can be both beneficial and harmful in the critically ill depending on such factors as the nutritional status of the host, the severity of the illness, and the relative balance between the systemic inflammatory response syndrome and compensatory anti-inflammatory response syndrome. Further studies are required to define optimal levels for provision of antioxidants in different diseases as well as the identification of which antioxidants or combinations are effective.

\section{SUMMARY AND CONCLUSIONS}

Malnutrition is a major contributor to the increased morbidity and mortality seen in critical illness. Percentage weight loss is a sensitive and specific tool that can be used at initial presentation to screen for and identify malnutrition effectively. Nutritional depletion developing subsequently is multifactorial and depends on the interactions among numerous mediators including the proinflammatory cytokines, the stress hormones of intermediary metabolism, along with the decrease in antioxidant defenses and the decreased levels and effectiveness of anabolic hormones. Proinflammatory cytokines, although essential for immune defense, can exert pathologic and even lethal effects when produced in excessive amounts. The catabolic response in certain tissues like muscle, which occurs as a normal part of the inflammatory response in part to support anabolism in other tissues like the liver and hemotopoietic tissue, also bears the risk for the ultimate development of malnutrition. Moreover, the resistance to the effects of anabolic hormones during critical illness impairs the utilization of exogenous nutrients. The precise way in which individual factors interact with each other to deter- 
mine the outcome of inflammation is largely unknown. It is now widely appreciated however that optimizing the supply of energy, protein, special fatty acids, and the major anabolic hormones and micronutrients so as to support the metabolic responses to injury can significantly affect the outcome in these patients. However, adequate nutrition support and effective therapeutic interventions require an understanding of the pathological processes taking place and the establishment of a balance between the benefits of nutritional/metabolic support and the risks involved with overaggressive feeding. Recent studies also demonstrate that genetic factors can play important roles in the intensity of inflammation and the quality of the response to nutritional therapy in individual patients. Clearly, further studies will be necessary to identify such factors and their interactions so as to achieve the desired efficacy of nutritional therapy in the management of disease-related malnutrition characteristic of critical illness.

\section{RECOMMENDATIONS AND FUTURE CHALLENGES}

For the future anabolic adjuvant therapy may be directed into other ways to reduce the intensity of the systemic inflammatory response. One way would be the use of anticytokine therapy, such as with IL-1 receptor antagonist (IL-1ra) or anti-TNF therapy, including anti-TNF antibodies, soluble TNF receptors, pentoxifyline, a xanthinederived agent known to inhibit the production of TNF $(166,167)$, and thalidomide (168-170). Certain pharmacological agents like $\beta$-blockers (171) and angiotensinconverting enzyme inhibitors (172) have been shown to reduce cytokine production in chronic congestive heart failure. Recently, angiotensin-converting enzyme inhibitors have also been shown to improve antioxidant status, nutritional status, and clinical outcome in chronic renal failure, another proinflammatory state (173). Similarly statins, which are widely used to improve cardiovascular outcome by reducing serum cholesterol, have been shown to work as well through their antioxidant action (174). Another potentially promising way is through the use of nutrients that can influence antioxidant status such as selenium, zinc, glutamine, cysteine or vitamin E, since it has now been convincingly shown that reactive oxygen species can exacerbate the systemic inflammatory response (175). The improved clinical outcome in critically ill patients (176) using immune-enhancing diets, which contain both immune- and antioxidant-enhancing nutrients and omega 3 fatty acids, which are anti-inflammatory, suggest that combination therapies may be particularly effective. Vitamin E, an important antioxidant nutrient, also has been shown to reduce cardiovascular disease and the cardiovascular end points in chronic renal failure (177). Dietary omega-3 fatty acid pus vitamin E has a significant immunomodulating effect and has been shown to prolong the survival of malnourished patients with generalized malignancy (178). In this regard the combination of anabolic hormones such as growth hormone, and/or IGF-I in conjunction with antioxidant or anti-inflammatory therapies might be worthy of study, particularly since the side effects of the former might be through the promotion of inflammation. Thus, the future looks bright for the development of new methods to improve anabolic nutritional therapies.

\section{REFERENCES}

1. Bistrian BR, Blackburn GL, Hallowell E, Heddle R. Protein status of general surgical patients. JAMA 1974;230:858-860. 
2. Bistrian BR, Blackburn GL, Vitale J, Cochran D, Naylor J. Prevalence of malnutrition in general medical patients. JAMA 1976;235:1567-1570.

3. Blackburn GL, Bistrian BR, Maini BS, Schlamm HT, Smith MF. Nutritional and metabolic assessment of the hospitalized patient. JPEN J Parenter Enteral Nutr 1977;1:11-22.

4. Blackburn GL, Thornton PA. Nutritional assessment of the hospitalized patient. Med Clin North Am 1979;63:11103-11115.

5. Wilmore DW. Catabolic illness. Strategies for enhancing recovery. N Engl J Med 1991;325:687-702.

6. Shaw JH, Wildbore M, Wolfe RR. Whole body protein kinetics in severely septic patients. The response to glucose infusion and total parenteral nutrition. Ann Surg 1987;205:288 -294.

7. Streat SJ, Beddoe AH, Hill GL. Aggressive nutritional support does not prevent protein loss despite fat gain in septic intensive care patients. J Trauma 1987;27:262-266.

8. Loder PB, Smith RC, Kee AJ, et al. What rate of infusion of intravenous nutrition solution is required to stimulate uptake of amino acids by peripheral tissues in depleted patients? Ann Surg 1990;211:360-368.

9. Lust G. Effect of infection on protein and nucleic acid synthesis in mammalian organs and tissues. Fed Proc 1966;25:1688-1694.

10. Tomkins AM, Garlick PJ, Schofield WN, Waterlow JC. The combined effects of infection and malnutrition on protein metabolism in children. Clin Sci 1983;65:313-324.

11. Wannemacher RW, Jr. Dupont HL, Pekarek RS, et al. An endogenous mediator of depression of amino acids and trace metals in serum during typhoid fever. J Infect Dis 1972;126:77-86.

12. Wannemacher RW Jr, Pekarek RS, Klainer AS, Bartelloni PJ, Dupont HL, Hornick RB, Beisel WR. Detection of a leukocytic endogenous mediator-like mediator of serum amino acid and zinc depression during various infectious illnesses. Infect Immun 1975;11:873-875.

13. Chang HR, Bistrian BR. The role of cytokines in the catabolic consequences of infection and injury. JPEN J Parenter Enteral Nutr 1998;22:156-166.

14. Edwards PD, Moldawer LL. Role of cytokines in the metabolic response to stress. Cur Opin Clin Nutr Metab Care 1998;1:187-190.

15. Blackwell TS, Christman JW. Sepsis and cytokines: current status. Br J Anaesth 1996;77:110-117.

16. Dofferhoff AS, Bom VJ, de Vries-Hospers HG, et al. Patterns of cytokines, plasma endotoxin, plasminogen activator inhibitor and acute phase proteins during the treatment of severe sepsis in humans. Crit Care Med 1992;20:185-192.

17. Yeh FL, Lin WL, Shen HD, Fang RH. Changes in circulating levels of interleukin 6 in burned patients. Burns 1999;25:131-136.

18. Strassmann G, Fong M, Kenney JS, Jacob CO. Evidence for the involvement of interleukin 6 in experimental cancer cachexia. J Clin Invest 1992;89:1681-1684.

19. Gardlund B, Sjolin J, Nilsson A, Roll M, Wickerts CJ, Wretlind B. Plasma levels of cytokines in primary septic shock in humans: correlation with disease severity. J Infect Dis 1995;172:296-301.

20. Damas P, Ledoux D, Nys M, et al. Cytokine serum level during severe sepsis in human IL-6 as a marker of severity. Ann Surg 1992;215:365-362.

21. Pinsky MR, Vincent JL, Deviere J, Alegre M, Kahn RJ, Dupont E. Serum cytokine levels in human septic shock. Relation to multiple-system organ failure and mortality. Chest 1993;103:565-575.

22. Rixen D. Siegel JH, Friedman HP. "Sepsis/SIRS," physiologic classification, severity stratification, relation to cytokine elaboration and outcome prediction in posttrauma critical illness. J Trauma 1996;41:581-598.

23. Stratakis CA, Mastorakos G, Chrousos GP. Interleukin-6 elevation in critically ill infants with sepsis and necrotizing enterocolitis. J Pediatr 1994;125:504.

24. Barton BE. IL-6-like cytokine and cancer cachexia: consequences of chronic inflammation. Immunol Res 2001;23:41-58.

25. Belec L, Meillet D, Gresengnet G, Gherardi RK. Increased tumor necrosis factor-alpha serum levels in patients with HIV wasting syndrome and euthyroid sick syndrome. J Acquir Immune Defic Syndr Hum Retrovirol 1995;8:212-214.

26. Verheul GA, de Jongh-Leuvenink K, Op de Coul AA, van Landeghem AA, van Puyenbroek MJ. Tumor necrosis factor and interleukin-6 in critical illness polyneuromyopathy. Clin Neurol Neurosurg 1994;96:300-304.

27. Aderka D, Englemann H, Hornik V, et al. Increased serum levels of soluble receptors for tumor necrosis factor in cancer patients. Cancer Res 1991;51:5602-5607. 
28. Schalkwijk CG, Poland DC, van Dijk W, Kok A, et al. Plasma concentration of C-reactive protein is increased in type I diabetic patients without clinical macroangiopathy and correlates with markers of endothelial dysfunction: evidence for chronic inflammation. Diabetologia 1999;42:351-357.

29. Panichi V, Migliori M, De Pietro S, et al. C-reactive protein as a marker of chronic inflammation in uremic patients. Blood Purif 2000;18:183-190.

30. Flores EA, Bistrian BR, Pomposelli JJ, Dinarello CA, Blackburn GL, Instfan N. Infusion of tumor necrosis factor/cachectin promotes muscle catabolism in the rat. A synergistic effect with interleukin 1. J Clin Invest 1989;83:1614-1622.

31. Ling PR, Schwartz JH, Jeevanandam M, Gauldie J, Bistrian BR. Metabolic changes in rats during a continuous infusion of recombinant interleukin-1. Am J Physiol Endocrinol Metab 1996;270:E305-E312.

32. Waterlow JCP, Garlick PJ, Millward DJ. Protein Turnover in Mammalian Tissues and in the Whole Body. Elsevier/North-Holland, Amsterdan, Netherlands, 1978.

33. Waterlow JC, Stephen JM. The measurement of total lysine turnover in the rat by intravenous infusion of L-[U-14C]lysine. Clin Sci 1967:33:489-506.

34. Pomposelli JJ, Palombo JD, Hamawy KJ, Bistrian BR, Blackburn GL, Moldawer LL. Comparison of different techniques for estimating rates of protein synthesis in vivo in healthy and bacteraemic rats. Biochem J 1985;226:37-42.

35. Ling PR, Bistrian BR, Blackburn GL, Istfan N. Effect of fetal growth on maternal protein metabolism in postabsorptive rat. Am J Physiol Endocrinol Metab 1987;252:E380-E342.

36. Istfan NW, Ling PR, Blackburn GL, Bistrian BR. Enhancement of tumor proteolysis by TNF-alpha: correlation of in vivo isotope estimates with growth. Am J Physiol Endocrinol Metab 1991;261:R106-R116.

37. Ling PR, Schwartz JH, Bistrian BR. Mechanisms of host wasting induced by administration of cytokines in rats. Am J Physiol Endocrinol Metab 1997;272:E333-E339.

38. Lang CH, Fan J, Cooney R, Vary TC. IL-1 receptor antagonist attenuates sepsis-induced alterations in the IGF system and protein synthesis. Am J Physiol Endocrinol Metab 1996;270:E430-E437.

39. Vary TC, Voisin L, Cooney RN. Regulation of peptide-chain initiation in muscle during sepsis by interleukin-1 receptor antagonist. Am J Physiol. 1996;271:E513-E520.

40. Cooney R, Kimball SR, Eckman R, Maish G III, Shumate M, Vary TC. TNF-binding protein ameliorates inhibition of skeletal muscle protein synthesis during sepsis. Am J Physiol 1999;276:E611-E619.

41. Zamir O, Hasselegren PO, James H, Higashiguchi T, Fisher JE. Effect of tumor necrosis factor or interleukin-1 on muscle amino acid uptake and the role of glucocorticoids. Surg Gynecol Obstet 1993;177:27-32.

42. Li YP, Reid MB. NF-kappaB mediates the protein loss induced by TNF-alpha in different skeletal muscle myotubes. Am J Physiol Regul Integr Comp Physiol 2000;279:R1165-R1170.

43. Goodman MN. Interleukin-6 induces skeletal muscle protein breakdown in rats. Proc Soc Exp Biol Med 1994;205:182-185.

44. Ling PR, Istfan NW, Colon E, Bistrian BR. Differential effects of interleukin-1 receptor antagonist in cytokine- and endotoxin-treated rats. Am J Physiol Endocrinol Metab 1995;268:E255-E261.

45. Chai Z, Gatti S, Toniatti C, Poli V, Bartfai T. Interleukin (IL)-6 gene expression in the central nervous system is necessary for fever response to lipopolysaccharide or IL-1 $\beta$ : a study in IL-6-deficient mice. J Exp Med 1996;183:311-316.

46. Tsujinaka T, Fujita J, Ebisui C, et al. Interleukin 6 receptor antibody inhibits muscle atrophy and modulates proteolytic systems in interleukin 6 transgenic mice. J Clin Invest 1996;97:244-249.

47. Ling PR, Bistrian BR, Mendez B, Istfan NW. Effects of systemic infusions of endotoxin, tumor necrosis factor, and interleukin-1 on glucose metabolism in the rat: relationship to endogenous glucose production and peripheral tissue glucose uptake. Metabolism 1994;43:279-284.

48. Mynarcik DC, McNurlan MA, Steigbigel RT, Fuhrer J, Gelato MC. Association of severe insulin resistance with both loss of limb fat and elevated serum tumor necrosis factor receptor levels in HIV lipodystrophy. J Acquir Immune Defic Syndr 2000;25:312-321.

49. Argiles JM, Lopez-Soriano FJ. Insulin and cancer. Int J Oncol 2001;18:683-687.

50. Hotamisligil GS, Peraldi P, Budavari A, Ellis R, White MF, Spiegelman BM. IRS-1-mediated inhibition of insulin receptor tyrosine kinase activity in TNF-alpha- and obesity-induced insulin resistance. Science 1996;271:665-668.

51. Lang $\mathrm{CH}$, Spitzer JA.Glucose kinetics and development of endotoxin tolerance during long-term continuous endotoxin infusion. Metabolism 1987;36:469-474. 
52. Fan J, Li YH, Wojnar MM, Lang CH. Endotoxin-induced alteration in insulin-stimulated phosphorylation of insulin receptor, IRS-1, and MAP kinase in skeletal muscle. Shock 1996;6:164-170.

53. Lang CH, Pollard V, Fan J, et al. Acute alterations in growth hormone-insulin-like growth factor axis in humans injected with endotoxin. Am J Physiol Endocrinol Metab 1997;273:R371-R378.

54. McCowen KC, Ling PR, Ciccarone A, et al. Sustained endotoxemia leads to marked down-regulation of early steps in the insulin-signaling cascade. Critical Care Med 2001;29:839-846.

55. Dimitriadis G, Leighton B, Parry-Billings M, et al. Effects of glucocorticoid excess on the sensitivity of glucose transport and metabolism to insulin in rat skeletal muscle. Biochem J 1997;321:707-712.

56. Bessey PQ, Brooks DC, Black PR, Aoki TT, Wilmore DW. Epinephrine acutely mediates skeletal muscle insulin resistance. Surgery. 1983;94:172-179.

57. McGuinness OP, Snowden RT, Moran C, Neal DW, Fujiwara T, Cherrington AD. Impact of acute epinephrine removal on hepatic glucose metabolism during stress hormone infusion. Metabolism. 1999;48:910-914.

58. Defalque D, Brandt N, Ketelslegers JM, Thissen JP. GH insensitivity induced by endotoxin injection is associated with decreased liver GH receptors. Am J Physiol Endocrinol Metab 1999;276:E565-E572.

59. Wolf M, Bohm S, Brand M, Kreymann G. Proinflammatory cytokines interleukin 1 beta and tumor necrosis factor alpha inhibit growth hormone stimulation of insulin-like growth factor I synthesis and growth hormone receptor mRNA levels in cultured rat liver cells. Eur J Endocrinol 1996;135:729-737.

60. Mao Y, Ling RR, Fitzgibbons TP, et al. Endotoxin-induced inhibition of growth hormone receptor signaling in rat liver in vivo. Endocrinology 1999;140:5505-5515.

61. Frost RA, Lang CH, Gelato MC. Transient exposure of human myoblasts to tumor necrosis factoralpha inhibits serum and insulin-like growth factor-I stimulated protein synthesis. Endocrinology 1997;138:4153-4159.

62. Ling PR, Boyce P, Chow JC, et al. Inhibition of response to a lower but not a higher dose euglycemic infusion of IGF-I in TNF-treated rats. JPEN J Parenter Enteral Nutr 1998;21:S2.

63. Fang CH, Li BG, James JH, Fischer JE, Hasselgren PO. Cytokines block the effects of insulin-like growth factor-I (IGF-I) on glucose uptake and lactate production in skeletal muscle but do not influence IGF-I-induced changes in protein turnover. Shock 1997;8:362-367.

64. Lang CH. IGF-I stimulates muscle glucose uptake during sepsis. Shock. 1996;5:22-27.

65. Auclair M, Vigouroux C, Desbois-Mouthon C, et al. Antiinsulin receptor autoantibodies induce insulin receptors to constitutively associate with insulin receptor substrate- 1 and -2 and cause severe cell resistance to both insulin and insulin-like growth factor I. J Clin Endocrinol Metab 1999;84:3197-3206.

66. Shimasaki S, Ling N. Identification and molecular characterization of insulin-like growth factor binding proteins (IGFBP-1, -2, -3, -4, -5, and -6). Prog Growth Factor Res 1991;3:243-266.

67. Samstein B, Hoimes ML, Fan J, Frost RA, Gelato MC, Lang CH. IL-6 stimulation of insulin-like growth factor binding protein (IGFBP)-1 production. Biochem Biophys Res Commun 1996;228:611-615.

68. Benbassat CA, Lazarus DD, Cichy SB, et al. Interleukin-1 alpha (IL-1 alpha) and tumor necrosis factor alpha (TNF alpha) regulate insulin-like growth factor binding protein-1 (IGFBP-1) levels and mRNA abundance in vivo and in vitro. Horm Metab Res 1999;31:209-215.

69. Baxter RC, Hawker FH, To C, Stewart PM, Holman SR. Thirty-day monitoring of insulin-like growth factors and their binding proteins in intensive care unit patients. Growth Horm IGF Res 1998;8:455-463.

70. Firth SM, McDougall F, McLachlan AJ, Baxter RC. Impaired blockade of insulin-like growth factor I (IGF-I)-induced hypoglycemia by IGF binding protein-3 analog with reduced ternary complex-forming ability. Endocrinology 2002;143:1669-1676.

71. Tayek JA, Manglik S, Abemayor E. Insulin secretion, glucose production, and insulin sensitivity in underweight and normal-weight volunteers, and in underweight and normal-weight cancer patients: a Clinical Research Center Study. Metabolism 1997;46:140-145.

72. Soares MJ, Piers LS, Shetty PS, Jackson AA, Waterlow JC. Whole body protein turnover in chronically undernourished individuals. Clin Sci 1994;86:441-446.

73. Duke JH Jr., Jorgensen SB, Broell JR, Long CL, Kinney JM. Contribution of protein to caloric expenditure following injury. Surgery 1970;68:168-174. 
74. Kinney M. Metabolic responses of the critically ill patient. Crit Care Clin 1995;11:569-585.

75. Flores EA, Bistrian BR, Pompposelli JJ, Dinarello C, Blackburn GL, Istfan NW. Infusion of tumor necrosis factor/cachectin promotes muscle catabolism in the rat. A synergistic effect with interleukin 1. J Clin Invest 1989;83:1614-1622.

76. Doweiko JP, Nompleggi DL. The role of albumin in human physiology and pathophysiology. Part III: Albumin and disease states. JPEN J Parenter Enteral Nutr. 1991;15:476-483.

77. Dietary Reference. Intakes for energy, carbohydrate, fiber, fat, fatty acids, cholesterol, protein, and amino acid (macronutrient). In: Food and Nutrition Board. Institute of Medicine. The National Academy Press, 2002, p. 465.

78. Wolfe RR, Goodenough RD, Burke JF, Wolfe MH. Response of protein and urea kinetics in burn patients to different levels of protein intake. Ann Surg 1983;197:163-171.

79. Greig P, Elwyn D, Askanazi J, Kinney JM. Parenteral nutrition in septic patients: Effect of increasing nitrogen intake. Am J Clin Nutr 1987;46:1040-1047.

80. Ishibashi N, Plank LD, Sando K, Hill GL. Optimal protein requirements during the first 2 weeks after the onset of critical illness. Crit Care Med 1998;26:1529-1535.

81. Bistrian BR, Babineau T. Optimal protein intake in critical illness? Crit Care Med 1998;26:1476-1477.

82. Montoya A, Gomez-Lechon MJ, Castell JV. Influence of branched-chain amino acid compostion of culture media on the synthesis of plasma proteins by serum-free cultured rat hepatocytes. In Vitro Cell Dev Biol 1989;25:358-364.

83. Kee AJ, Baxter RC, Carlsson AR, Smith RC. Parenteral amino acid intake alters the anabolic actions of insulin-like growth factor I in rats. Am J Physiol Endocrinol Metab 1999;277:E63-E72.

84. Sanchez-Gomez M, Malmlof K, Mejia W, et al. Insulin-like growth factor-I, but not growth hormone, is dependent on a high protein intake to increase nitrogen balance in the rat. $\mathrm{Br} \mathrm{J}$ Nutr 1999;81:145-152.

85. Isidori A, Lo Monaco A, Cappa M. A study of growth hormone release in man after oral administration of amino acids. Curr Med Res Opin 1981;7:475-481.

86. Yahya ZA, Bates PC, Millward DJ. Responses to protein deficiency of plasma and tissue insulin-like growth factor-I levels and proteoglycan synthesis rates in rat skeletal muscle and bone. J Endocrinol 1990;127:497-530.

87. Jousse C, Bruhat A, Ferrara M, Fafournoux P. Physiological concentration of amino acids regulates insulin-like-growth factor-binding protein 1 expression. Biochem J 1998;334:147-153.

88. Houdijk A, Rijnsburger ER, Jansen J, Wesdorp RI, Weiss JK, McCamish MA, et al. Randomised trial of glutamine-enriched enteral nutrition on infectious morbidity in patients with multiple truama. Lancet 1998;352:772-776.

89. Kudsk KA, Minard G, Croce MA, et al. A randomized trial of isonitrogenous enteral diets after severe trauma. An immune-enhacing diet reduces septic complications. Ann Surg 1996;224:531-540.

90. Wilmore DW. The effect of glutamine supplementation in patients following elective surgery and accidental injury. J Nutr 2001;131:2543S-2549S.

91. Lin MT, Kung SP, Yeh SL, et al. The effect of glutamine-supplemented total parenteral nutrition on nitrogen economy depends on severity of diseases in surgical patients. Clin Nutr 2002;21:213-218.

92. Evoy D, Lieberman MD, Fahey TJ 3rd, Daly JM. Immunonutrition: the role of arginine. Nutrition 1998;14:611-617.

93. Yeh CL, Yeh SL, Lin MT, Chen WJ. Effects of arginine-enriched total parenteral nutrition on inflammatory-related mediator and T-cell population in septic rats. Nutrition 2002;18:631-635.

94. Gil A. Modulation of the immune response mediated by dietary nucleotides. Eur J Clin Nutr 2002;56:S1-S4.

95. van den Berghe G, Wouters $\mathrm{P}$, Weekers F, et al. Intensive insulin therapy in the critically ill patients. N Engl J Med 2001;345:1359-1367.

96. McCowen KC, Malhotra A, Bistrian BR. Stress-induced hyperclycemia. Crit Care Clin 2000;17:107-124.

97. McCowen KC, Friel C, Sternberg J, et al. Hypocaloric total parenteral nutrition: Effectiveness in prevention of hyperglycemia and infectious complications-A randomized clinical trial. Crit Care Med 2000;28:3606-3611.

98. Rosmarin DK, Wardlaw GM, Mirtallo J. Hyperglycemia associated with high, continuous infusion rate of total parenteral nutrition dextrose. Nutr Clin Pract 1996;11:151-156. 
99. Pomposelli JJ, Baxter JK III, Babineau TJ, et al. Early postoperative glucose control predicts nosocomial infection rate in diabetic patients. JPEN J Parenter Enteral Nutr 1998;22:77-81.

100. Guha M, Bai W, Nadler JL, Natarajan R. Molecular mechanisms of tumor necrosis factor alpha gene expression in monocytic cells via hyperglycemia-induced oxidant stress-dependent and -independent pathways. J Biol Chem 2000;275:17728-17739.

101. Yerneni KK, Bai W, Khan BV, Medford RM, Natarajan R. Hyperglycemia-induced activation of nuclear transcription factor kappaB in vascular smooth muscle cells. Diabetes 1999;48:855-864.

102. Kwoun MO, Ling PR, Lydon E, et al. Immunologic effects of acute hyperglycemia in nondiabetic rats. J Parenter Enteral Nutr. 1997;21:91-95.

103. Zerr KJ, Furnary AP, Grunkemeier GL, Bookin S, Kanhere V, Starr A. Glucose control lowers the risk of wound infection in diabetics after open heart operations. Ann Thorac Surg. 1997;63:356-361.

104. Furnary AP, Zerr KJ, Grunkemeier GL, Starr A. Continuous intravenous insulin infusion reduces the incidence of deep sternal wound infection in diabetic patients after cardiac surgical procedures. Ann Thorac Surg 1999;67:352-360.

105. Malmberg K. Prospective randomized study of intensive insulin treatment on long term survival after acute myocardial infarction in patients with diabetes mellitus: DIGAMI (Diabetes Mellitus, Insulin Glucose Infusion in Acute Mayocadial Infarction) Study Group. BMJ 1997;314:1512-1515.

106. Ling PR, Lydon E, Qu Zh, Frederich RC, Bistrian BR. Metabolic effects of insulin and insulin-like growth factor-I in endotoxemic rats during total parenteral nutrition feeding. Metabolism 2000;49:611-615.

107. Patino JF, de Pimiento SE, Vergara A, Savino P, Rodriguez M, Escallon J. Hypocaloric support in the critically ill. World J Surg 1999;23:553-559.

108. Macfie J, Smith RC, Hill GL. Glucose or fat as nonprotein energy source ? A controlled clinical trial in gastroenterological patients requiring intravenous nutrition. Gastroenterology 1981;80:103-107.

109. Paulsrud JR, Pensler L, Whitten CF, Stewart S, Holman RT. Essential fatty acid deficiency in infants induced by fat-free intravenous feeding. Am J Clin Nutr 1972;25:897-904.

110. Fleming CR, Smiht LM, Hodges RE. Essential fatty acid deficiency in adults receiving total parenteral nutrition. Am J Clin Nutr 1976;29:976-983.

111. Wene JD, Connor WE, DenBesten L. The development of essential fatty acid deficiency in healthy man fed fat-free diets intravenously and orally. J Clin Invest 1975;56:127-134.

112. Kamara K, Eskay R, Castonguay T. High-fat diets and stress responsivity. Physiol Behav 1998;64:1-6.

113. Klein S, Miles JM. Metabolic effects of long-chain and medium-chain triglyceride emulsions in humans. JPEN J Parenter Enteral Nutr 1994;18:396-397.

114. Barr LH, Dunn GD, Brennan MF. Essential fatty acid deficiency during total parenteral nutrition. Ann Surg 1981;193:304-311.

115. Innis SM. Essential fatty acid requirements in human nutrition. Can J Physiol Pharmacol 1993;71:699-706.

116. Endres S, Ghorbani R, Kelley VE, et al. The effects of dietary supplementation with n-3 polyunsaturated fatty acids on the synthesis of interleukin-1 and tumor necrosis factor by mononuclear cells. $\mathrm{N}$ Engl J Med 1989;320:265-271.

117. Pomposelli JJ, Mascioli EA, Bistrian BR, Lopes SM, Blackburn GL. Attenuation of the febrile response in guinea pigs by fish oil enriched diets. J Parenterl Enteral Nutr 1989;13:136-140.

118. Pscheidl EM, Wan JM, Blackburn GL, Bistrian BR, Istfan NM. Influence of omega-3 fatty acids on splanchnic blood flow and lactate metabolism in an endotoxinemic rat model. Metabolism 1992;41:698-705.

119. Ling PR, Istfan N, Colon E, Bistrian BR. Effect of fish oil on glucose metabolism in the interleukin-1 alph-treated rat. Metabolism 1993;42:81-85.

120. Tashiro T, Yamamori H, Takagi K, Hayashi N, Furukawa K, Nakajima N. n-3 versus n-6 polyunsaturated fatty acids in critical illness. Nutrition 1998;14:551-553.

121. Volker D, Fitzgerald P, Major G, Garg M. Efficacy of fish oil concentrate in the treatment of rheumatoid arthritis. J Rheumatol 2000;27:2343-2346.

122. Darlington LG, Stone TW. Antioxidants and fatty acids in the amelioration of rheumatoid arthritis and related disorders. Br J Nutr 2001;85:251-269.

123. Geerling BJ, Badart-Smook A, van Deursen C, van Houwelingen AC, Russel MG, Stockbrugger $\mathrm{RW}$, et al. Nutritional supplementation with N-3 fatty acids and antioxidants in patients with 
Crohn's disease in remission: effects on antioxidant status and fatty acid profile. Inflamm Bowel Dis 2000;6:77-84.

124. Ling SC, Griffiths AM. Nutrition in inflammatory bowel disease. Curr Opin Clin Nutr Metab Care 2000;3:339-344.

125. Santos J, Queiros J, Silva F, et al. Effects of fish oil in cyclosporine-treated renal transplant recipients. Transplant Proc. 2000;32:2605-2608.

126. Ghoshal AK, Xu Z, Wood GA, Archer MC. Induction of hepatic insulin-like growth factor binding protein-1 (IGFBP-1) in rats by dietary n-6 polyunsaturated fatty acids. Pro Soc Exp Biol Med. 2000;225:128-135.

127. Curtis-Prior M: Prostaglandins: Biology and Chemistry of Prostaglandins and Related Eicosanoids. Churchill-Livingston, New York,. 1988.

128. Parker CW Lipid mediators produced through the lipoxygenase pathway. Ann Rev Immunol 1987;5:65-84.

129. Kinsella JE, Lokesh B, Broughton S, Whelan J. Dietary polyunsaturated fatty acids and eicosanoids: potential effects on the modulation of inflammatory and immune cells: an overview. Nutrition 1990;6:24-44.

130. Lands WE. Biochemistry and physiology of w3 fatty acids. FASEB J 1992;6:2530-2536.

131. Mayer K, Seeger W, Grimminger F. Clinical use of lipids to control inflammatory disease. Curr Opin Clin Nutr Metab Care 1998;1:179-184.

132. Zadak Z, Cervinkova Z. PUFA n-3 lipid emulsion: a promising agent in ARDS treatment. Nutrition 1997;13:232-233.

133. Baronzio G, Freitas I, Griffini P, et al. Omega-3 fatty acids can improve radioresponse modifying tumor interstitial pressure, blood rheology and membrane peroxidability. Anticancer Res 1994;14:1145-1154.

134. Rose DP, Connolly JM. Omega-3 fatty acids as cancer chemopreventive agents. Pharmacol Ther 1999;83:217-244.

135. Jeffery NM, Newsholme EA, Calder PC. Level of polyunsaturated fatty acids and the n-6 to n-3 polyunsaturated fatty acid ratio in the rat diet alter serum lipid levels and lymphocyte functions. Prostaglandins Leukot Essent Fatty Acids 1997;57:149-160.

136. Wachtler P, Konig W, Senkal M, Kemen M, Koller M. Influence of a total parenteral nutrition enriched omega-3 fatty acids on leukotriene synthesis of peripheral leukocytes and systemic cytokine levels in patients with major surgery. J Trauma 1997;42:191-198.

137. Lanza-Jacoby S, Flynn JT, Miller S. Parenteral supplementation with a fish-oil emulsion prolongs survival and improves rat lymphocyte function during sepsis. Nutrition 2001;17:112-116.

138. Wigmore SJ, Ross JA, Falconer JS, et al. The effect of polyunsaturated fatty acids on the progress of cachexia in patients with pancreatic cancer. Nutrition 1996;12:S27-S30.

139. Barber MD, Ross JA, Voss AC, Tisdale MJ, Fearon KC. The effect of an oral nutrition supplement enriched with fish oil on weight-loss in patients with pancreatic cancer. Br J Cancer 1999;81:80-86.

140. Barber MD, McMillan DC, Preston T, Ross JA, Fearon KC. Metabolic response to feeding in weightlosing pancreatic cancer patients and its modulation by a fish-oil-enriched nutritional supplement. Clin Sci 2000;98:389-399.

141. Wigmore SJ, Barber MD, Ross JA, Tisdale MJ, Fearon KC. Effect of oral eicosapentaenoic acid on weight loss in patients with pancreatic cancer. Nutr Cancer 2000;36:177-184.

142. Ponting GA, Halliday D, Teale JD, Sim AJ. Postoperative positive nitrogen balance with intravenous hyponutrition and growth hormone. Lancet 1988;1:438-440.

143. Manson JM, Smith RJ, Wilmore DW. Growth hormone stimulates protein synthesis during hypocaloric parenteral nutrition: Role of hormonal-substrate environments. Ann Surg 1988;208: 136-142.

144. Gore DC, Honeycutt D, Jahoor F, Wolfe RR, Herndon DN. Effect of exogenous growth hormone on whole-body and isolated-limb protein kinetics in burned patients. Arch Surg 1991;126:38-43.

145. Jeevanandam M, Ali MR, Holaday NJ, Petersen SR. Adjuvant recombinant human growth hormone normalizes plasma amino acids in parenterally fed trauma patients. JPEN J Parenter Enteral Nutr 1995;19:137-144.

146. Voerman BJ, Strack van Schijndel RJ, Groeneveld AB, de Boer H, Nauta JP, Thijs LG. Effects of human growth hormone in critically ill nonseptic patients: results from a prospective, randomized, placebo-controlled trial. Crit Care Med 1995;23:665-673. 
147. Carli F, Webster JD, Halliday D. Growth hormone modulates amino acid oxidation in the surgical patient: leucine kinetics during the fasted and fed state using moderate nitrogenous and caloric diet and recombinant human growth hormone. Metabolism. 1997;46:23-28.

148. Carli F, Webster JD, Halliday DA. A nitrogen-free hypocaloric diet and recombinant human growth hormone stimulate postoperative protein synthesis: fasted and fed leucine kinetics in the surgical patients. Metabolism 1997;46:796-800.

149. Schambelan M, Mulligan K, Grunfeld C, et al. Recombinant human growth hormone in patients with HIV-associated wasting. A randomized, placebo-controlled trial. Serostin Study Group. Ann Intern Med. 1996;125:873-882.

150. Takala J, Ruokonen E, Webster NR, et al. Increased mortality associated with growth hormone treatment in critically ill adults. N Eng J Med 1999;341:785-792.

151. Tayek JA, Brasel JA. Failure of anabolism in malnourished cancer patients receiving growth hormone: a clinical research center study. J Clin Endocrino Metab 1995;80:2082-2087.

152. Jenkins RC, Ross RJ. Acquired growth hormone resistance in catabolic states. Baillieres Clin Endocrinol Metab 1996;10:411-419.

153. Handelsman DJ, Liu PY. Androgen therapy in chronic renal failure. Baillieres Clin Endocrinol Metab 1998;12:485-500.

154. Corcoran C, Grinspoon S. The use of testosterone in the AIDS wasting syndrome. AIDS Clin Care 1999;11:25-26, 33-34.

155. Strawford A, Barbieri T, Van Loan M, et al. Resistance exercise and supraphysiologic androgen therapy in eugonadal men with HIV-related weight loss: a randomized controlled trial. JAMA 1999;281:1282-1290.

156. Horton JW, White DJ, Maass DL, Hybki DP, Handek S, Giroir B. Antioxidant vitamin therapy alters burn trauma-mediated cardiac NF-kappaB activation and cardiomyocyte cytokine secretion. J Trauma 2001;50:397-406.

157. Fu Z, Noguchi T, Kato H. Vitamin A deficiency reduces insulin-like growth factor (IGF)-I gene expression and increases IGF-I receptor and insulin receptor gene expression in tissues of Japanese quail (Coturnix coturnix japonica). J Nutr 2001;131:1189-1194.

158. Ninh NX, Maiter D, Lause P, et al. Continuous administration of growth hormone does not prevent the decrease of IGF-I gene expression in zinc-deprived rats despite normalization of liver GH binding. Growth Horm IGF Res 1998;8:465-472.

159. Angstwurm MW, Schottdorf J, Schopohl J, Gaertner R. Selenium replacement in patients with severe systemic inflammatory response syndrome improves clinical outcome. Crit Care Med 1999;27:1807-1813.

160. Preiser JC, Van Gossum A, Berre J, Vincent JL, Carpentier Y. Enteral feeding with a solution enriched with antioxidant vitamins $\mathrm{A}, \mathrm{C}$ and $\mathrm{E}$ enhances the resistance to oxidative stress. Crit Care Med 2000;28:3828-3832.

161. Ziegler TR, Young LS, Benfell K, et al. Clincial and metabolic efficacy of glutamine-supplemented parenteral nutrition after bone marrow transplantation. A randomized, double-blind, controlled study. Ann Intern Med 1992;116:821-828.

162. Schloerb PR, Skikne BS. Oral and parenteral glutamine in bone marrow transplantation: a randomized, double-blind study. JPEN J Parenter Enteral Nutr 1999;23:117-122.

163. Morlion B, Stehle P, Wachtler P, et al. Total parenteral nutrition with glutamine dipeptide after major abdominal surgery: a randomized, double-blind controlled study. Ann Surg 1998;227:302-308.

164. Houdijk AP, Rijnsburger ER, Jansen J, et al. Randomised trial of glutamine-enriched enteral nutrition on infectious morbidity in patients with multiple trauma. Lancet. 1998;352:772-776.

165. Kudsk KA, Minard G, Croce M, et al. A randomized trial of isonitrogenous enteral diets after severe trauma. An immune-enhancing diet reduces septic complications. Ann Surg 1996;224:531-540.

166. Paradowski PT, Zeman K, Pietruszynski R. Pentoxifylline inhibits tumor necrosis factor alphainduced priming of human neutrophils. Immunol Lett 1996;53:131-134.

167. Porter MH, Hrupka BJ, Altreuther G, Arnold M, Langhans W. Inhibition of TNF-alpha production contributes to the attenuation of LPS-induced hypophagia by pentoxifylline. Am J Physiol Regul Integr Comp Physiol. 2000;279:R2113-2120.

168. Fu CS, Conteas CN, LaRiviere MJ. Successful treatment of idiopathic colitis and proctitis using thalidomide in person infected with human immunodeficiency virus. AIDS Patient Care STDS 1998;12:903-906. 
169. Corral LG, Muller GW, Moreira AL, et al. Selection of novel analogs of thalidomide with enhanced tumor necrosis factor alpha inhibitory activity. Mol Med 1996;2:506-515.

170. Keifer JA, Guttridge DC, Ashburner BP, Baldwin AS Jr. Inhibition of NF-kappa B activity by thalidomide through suppression of Ikappa B kinase activity. J Biol Chem 2001;276:22382-22387.

171. Ohtsuka T, Hamada M, Hiasa G, et al. Effect of beta-blockers on circulating levels of inflammatory and anti-inflammatory cytokines in patients with dilated cardiomyopathy. J Am Coll Cardiol 2001;37:412-417.

172. Skudicky D, Bergemann A, Sliwa K, Candy G, Sareli P. Beneficial effects of pentoxifylline in patients with idiopathic dilated cardiomyopaty treated with angiotension-converting enzyme inhibitors and carvedilol: results of a randomized study. Circulation 2001;103:1083-1088.

173. Stenvinkel P, Andersson P, Wang T, et al. Do ACE-inhibitors suppress tumor necrosis factor-alpha production in a advanced chronic renal failure? J Intern Med 1999;246:503-507.

174. Ridker P, Rifai N, Clearfield M, et al. Measurement of C-reactive protein for the targeting of statin therapy in the primary prevention of acute coronary events. N Engl J Med 2001;344:1959-1965.

175. Davies MG, Hagen PO. Systemic inflammatory response syndrome. Br J Surg. 1997;84:920-935.

176. Galban C, Montejo JC, Mesejo A, et al. An immune-enhancing enteral diet reduces mortality rate and episodes of bacteremia in septic intensive care unit patients. Crit Care Med 2000;28:643-648.

177. Mune M, Yukawa S, Kishino M, et al. Effect of vitamin E on lipid metabolism and atherosclerosis in ESRD patients. Kidney Int Suppl 1999;71:S126-S129.

178. Gogos CA, Ginopoulos P, Salsa B, Apostolidou E, Zoumbos NC, Kalfarentzos F. Dietary omega-3 polyunsaturated fatty acids plus vitamin $\mathrm{E}$ restore immunodeficiency and prolong survival for severely ill patients with generalized malignancy: a randomized control trial. Cancer 1998;82:395-402. 